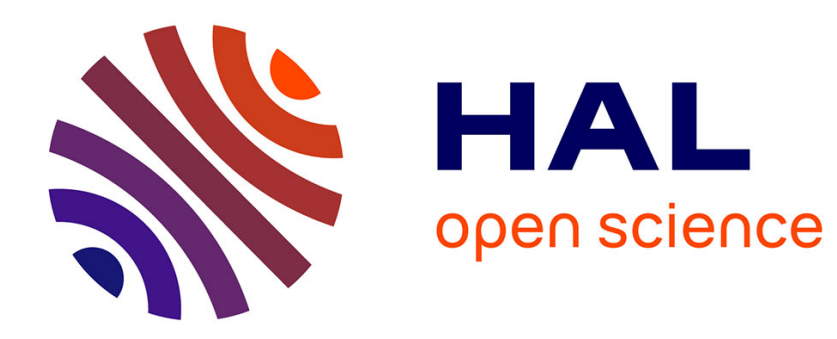

\title{
The Third sector in Europe; Does it exhibit a converging movement?
}

\author{
Edith Archambault
}

\section{To cite this version:}

Edith Archambault. The Third sector in Europe; Does it exhibit a converging movement?. B. Enjolras and K.H. Sivesind. Civil Society in Comparative Perspective, Emerald Books, pp.3-24, 2009, Comparative Social Research, vol. 26. halshs-00311749

\section{HAL Id: halshs-00311749 \\ https://shs.hal.science/halshs-00311749}

Submitted on 20 Aug 2008

HAL is a multi-disciplinary open access archive for the deposit and dissemination of scientific research documents, whether they are published or not. The documents may come from teaching and research institutions in France or abroad, or from public or private research centers.
L'archive ouverte pluridisciplinaire HAL, est destinée au dépôt et à la diffusion de documents scientifiques de niveau recherche, publiés ou non, émanant des établissements d'enseignement et de recherche français ou étrangers, des laboratoires publics ou privés. 


\section{The Third sector in Europe: Does it exhibit a converging movement?}

\section{Edith Archambault, Emeritus professor, University Paris1 Panthéon-Sorbonne Centre d'économie de la Sorbonne}

European Union is widening step-by-step, passing from the six member-states of the origin in 1957, Belgium, France, Germany, Italy, Luxemburg, Netherlands, to 27 member-states in 2007 , including recently the bulk of post-communist countries. In this integration movement, European Union is often compared with the United States owing to its population or its GDP: a larger population in European Union, 490 million inhabitants, than in the United States, 300 million, while the European and American GDP are of the same order of magnitude, respectively 10917 billion $€$ and 10037 billion $€$ in 2006 .

Beyond this economic point of view, the resemblance between both regions stops. In opposition to the United States, the European member-states do not share a common historical background, a common language, a common foreign policy or a democratically decided income redistribution system among the richer and the poorer member-states. These features are at the roots of the concept of citizenship and as we remarked a few years ago (Archambault, 2000), there is not yet any kind of European citizenship.

What are the main differences between European and US nonprofit sectors? Firstly in Europe there is everywhere a kind of partnership between the Third sector and central or local governments and social security as well, while in the US its competition with public agencies and private for profit corporations is more visible. This difference reflects in the structure of the resources of the Third sector both sides of the Atlantic: the main source of income in Europe is public funding, whether grants or contracts, when the American nonprofit organizations rely mainly on fees, charges and other private earned income. Secondly, we find in Europe a strong ideological competition inside the Third sector rooted in a long history tracing back to the Middle Ages for charitable organizations run initially by the Church and to the $19^{\text {th }}$ century workers movement for organizations more or less linked with the labor unions. By contrast, the US nonprofit organizations seem to be less dependent of the workers movement and more marked by the self-help principle of the pioneers, as Tocqueville pointed out $^{1}$, and also by the Puritan ideology according to which you have to "give back to the community" and consider volunteering as the best use of spare time. Thirdly, in Europe the nonprofit sector is embedded in a larger set of organizations called social economy, including cooperatives and mutual societies, supported by the Brussels institutions and viewed by some authors as an alternative to shareholder driven capitalism. By contrast, in the US the concept of social economy does not exist: cooperatives and mutual societies are considered as standard businesses after the 1980s demutualization trend.

However the European Union's third sector is not uniform; it shows five clusters of civil society organizations with complex bonds and ties with the surrounding societies and national identities. We will analyze in a first part these five clusters, Continental, Anglo-Saxon, Nordic, Mediterranean and Oriental, according to their political, social and economic

\footnotetext{
${ }^{1}$ Tocqueville ( 1835 ) : « Partout où, à la tête d'une entreprise nouvelle, vous voyez en France le gouvernement et en Angleterre un grand seigneur, comptez que vous apercevrez aux Etats-Unis une association. » : " In any new endeavour's leadership, you can see in France the government and in England a landlord, but in the USA you will find an association »
} 
background $^{2}$ and main features and use the data issued from the Johns Hopkins Comparative Nonprofit Sector Project ${ }^{3}$ (Salamon et alii, 2004). The second part of this paper is devoted to the question of a likely convergent evolution of these five clusters, according to a mimetic movement that we can observe in the European Commission's policy to disseminate the "best practices" but also as a bottom-up trend of civil society organizations working cross-country.

\section{Five clusters inside the European pattern of Third sector}

The theoretical approach of the five clusters relies on the distinction of the three welfare state regimes proposed by Esping-Andersen (1990, 1999, 2003). Indeed Europe as a whole provides the highest level of social protection and the widest "decommodification" of this social protection. Therefore the bulk of nonprofit organizations - and not only those providing education, health and social services - cannot be understood without a reference to the kind of welfare state that shaped the whole modern society. The change or crisis of the welfare state over time gives indeed new opportunities to the Third sector. We refer also to the Social origins theory (Salamon and Anheier, 1997), more global and complex, and try to make it more specific in the European Union, because 16 countries over 27 were included in the second phase of the Johns Hopkins Nonprofit Sector Comparative project (CNP2; Salamon, Anheier and associates 2004).

These theories inspire the first part of the table given in annex that shows the framework of the clusters according to :

- The relationship to the government (central/local, high/low level of taxation)

- The main religions and their links with parts of the Third sector

- The labour market situation (unemployment, flexibility, security) with a special attention devoted to women employment, full time or part time, in relation with volunteering.

- The ratio of social protection to GDP, the share of public social expenditure and the dominant type of social security regime

- The composition of Social economy ${ }^{4}$.

Then we confront the five clusters with the data of CNP2 (human resources inside the Third sector, origin of the resources) with this political, religious, social and economic background.

The five clusters isolated are the following:

- The Continental or corporatist cluster

- The Anglo-Saxon or liberal cluster

- The Nordic or socio-democrat cluster

- The Mediterranean or emerging cluster

- The Oriental or post-communist cluster

\subsection{The Continental or corporatist cluster}

\footnotetext{
${ }^{2}$ Neglecting because of the limited dimension of this paper the most important and complex one, the historical background (Salamon and Anheier, 1997, Archambault, 2001)

${ }^{3}$ Hereafter designed as CNP2

${ }^{4}$ Social economy, a concept of French origin, includes cooperatives, mutual societies, associations and foundations. This concept is now used by European Union institutions. For an analytical point of view, see Archambault and Kaminski, 2004
} 
This cluster includes Austria, Belgium, France, Germany, Italy and the Netherlands. Except Austria, these countries were at the origin of European Union in 1957. Switzerland belongs also to this pattern, though not inside European Union.

In these countries, the nonprofit sector is large and embedded in a political system tending to bipartisan and a decentralized administrative system by a long lasting partnership. In this federalist context, the subsidiarity principle implies that the government does not provide a service if the family, the local government or a nonprofit organization has coped with the concerned social issue. The social protection is rather high, with a high level of public social spending and a "Bismarckian" form of Social security, that is social insurance on a professional and corporatist basis. This high social security combines with a labor market with low flexibility and the unemployment rate is rather high in the countries of this cluster, except Austria and the Netherlands. Many NPOs were therefore created to help the unemployed to find or resume work and join the mainstream. According to the Bismarckian Social security scheme, married women are protected by the health insurance of their husband; in consequence they are not incited to work. Despite this fact, during the last decades women participation to labour market increased dramatically in all countries, creating new fields for the nonprofit sector such as child and dependent elderly care. Part-time female employment increased as a partial answer to child care and a way of reducing unemployment.

Catholic mainly or mixing Catholicism and protestantism, the countries of this cluster have nonprofit organizations marked by religious or political affiliation. This is the pillarization system, culminating in the Netherlands: in this country people used to stay in their Catholic or Protestant segment from the cradle to the grave, each pillar having its own newspapers, economic interest organizations, labor-unions, political parties, radio and TV broadcasting associations and of course schools. Competition between both religions is an encouragement to developing nonprofit organizations. In most countries, except France, the religions have a quasi-public status. In Germany, for instance, the church-tax finances religious activities and a part of the health or social activities linked to the Catholic or Protestant pillars, while Catholic schools predominate in Belgium or Netherlands.

In these countries, the nonprofit sector is large and its paid and volunteer work force is 8 per cent of total employment in average. It is composed mainly of large organizations, some of them dating back to the Middle Ages. These organizations are federated according to religious or political lines as said earlier: Catholic, socialist and liberal pillars in Belgium, Catholic and secular in France and Italy; socialist, Protestant and Catholic in Germany. Most nonprofit organizations are very professional (with an average paid/volunteer work ratio of 1.9) and rely less on volunteering in Germany, Austria, Belgium and Italy than in France or the Netherlands. Conversely there are also many recent citizen initiatives creating small voluntary associations on advocacy, cultural or recreation purposes. Large nonprofits are mainly funded by governments or social security, according to the subsidiarity principle; therefore it is in the Continental cluster that public funding is the highest in Europe, 58 per cent on average. Fees and charges are relatively low as well as individual and corporate giving. Grant-making foundations are growing in all countries, except France, and they become financial intermediaries. Large scale cooperatives of all kind exist in all countries of the Continental cluster: mutual societies provide health and insurance services, everywhere except Italy and more than elsewhere in France and cooperative banks are indeed the main financial partner of the Third sector. In this cluster there is an official reference to social economy and in some countries the state encourages networking among social economy organizations. 
The partnership with public powers is ancient: labor-unions, professional organizations as well as the welfare associations are partners in drafting, testing and implementing the public policy concerning their fields. The government specifies the quantity and quality of services to be produced and controls the output; different kinds of agreements and regulations precise the partnership with the state, local government or Social security, often with a public funding valid for a number of years. Nonprofit organizations have the state (federal or federated) as their main partner in education and research, the local governments in culture and sports, social services and local development and social security in the health and social services fields. The Socio-Economic Council that gathers representatives of the so called organised civil society ${ }^{5}$ is the top of this corporatist framework.

\subsection{The Anglo-Saxon or liberal cluster}

United Kingdown and Ireland follow the European version of the Anglo-Saxon countries liberal ideal-type, more represented in North America (USA and Canada) and in Oceania (Australia and New Zealand). The NPOs in UK are in a closer relationship with government than their counterparts in overseas countries, the former British Empire.

In UK and Ireland, the political background is centralized, but local governments are strong and their power is growing. The tax level is lower than in the continental pattern. Contrasting with the preceding cluster, the labor market is flexible, with a low security and a low employment rate, meaning a high job turn-over. The level of women employment is high, but as most of them work part-time, this leaves them time to care their children or volunteer. Volunteerism indeed is high, rooted in history and included in school curriculum and it is considered as a way of socialization.

The welfare state was initially Beveridgian, that is universalistic, based on citizenship and funded by tax. However since the Thatcher's era the social protection was declining in UK. More and more means tested benefits appear transforming the Beveridgian social security system into assistance. In Ireland social protection was low and remains under such conditions for competitive reasons.

In UK, the hegemonic religion is Protestantism and Catholicism in Ireland. The competition through nonprofit organizations among religious denominations or congregations inside the main religion, as well as among ethnic communities in countries with high immigration, provoked the growth of the nonprofit sector. Another cause of this growth is the contractingout behaviour of central and local governments in the field of social services, health and education, which is a way of privatization of the Welfare state.

The Anglo-saxon cluster relies on voluntary organizations of all sizes. This term insists on the symbolic function of volunteering, relying on a long-lasting tradition of private initiative, individualism and Puritanism (or Catholic charity in Ireland). In the USA, philanthropic initiative is traditionally opposed to central government bureaucracy, while in the European islands, it works in close partnership with town councils and other municipal powers.

\footnotetext{
${ }^{5}$ The Socio-Economic Council gathers representatives of agriculture, manufacturing and service industries, of crafts and commerce, of cooperatives, mutual societies and associations. That is any organization, for profit or nonprofit, but the public sector. This large scope contrasts with the common acceptation of civil society.
} 
Inside nonprofit organizations volunteer and paid work mix rather well. The core of the nonprofit sector is composed of charities ${ }^{6}$. Paid employment goes first to education, the main sector in both countries, private universities mainly in UK and catholic schools in Ireland; then it is directed towards health in Ireland and social services in UK. Volunteering is mainly oriented as everywhere in Europe towards culture, sports and recreation, then social services and local development. Wage-earners are skilled and the top staff graduated in nonprofit management or other focused curriculum. Umbrellas gather voluntary organizations according to either ideological lines or activities. These umbrellas provide regular statistical data on charities and they create self-controlled ethical rules.

These independent and private organizations have a greater variety of resources than in the other patterns. Public resources are shifting from grants to contracts, often in competition with other nonprofits or standard businesses. Donations are higher than elsewhere and private earnings are diversified: lotteries, charitable shops, ethical investments, deductions on the wage-bill, giving checks are British innovations which spread on the Continental countries. Finally foundations and trusts are decisive financial intermediaries.

\subsection{The Nordic or socio-democrat cluster}

In the countries belonging to the Nordic cluster, maybe the most specific, Denmark, Finland, Norway and Sweden, socio-democrat governments ruled with few alternation during the whole $20^{\text {th }}$ century. These countries are small, centralized and local governments have less power than in the preceding clusters. Owing to a high tax level, accepted by the population, the socio-democrat welfare state provides directly education, health and social services. Only one per cent of students, for instance, attend a private school in Sweden (Lundstrom and Wijkstrom, 1995). The social security scheme is Beveridgian that is unique, universal and uniform and funded by tax.

In these countries, the Third sector is smaller than in the preceding clusters (6.4 per cent of total employment comparing to 8 per cent in the Continental and 9.4 per cent in the AngloSaxon clusters). It is called voluntary as in Anglo-Saxon countries but the term of charity has a negative connotation as in the Continental cluster. Though some parts of this voluntary sector trace back to the popular movements of the end of the $19^{\text {th }}$ century, its main part is more recent than in the preceding clusters. It is composed of small organizations merging in umbrellas according to their main activity. In the welfare state fields, education, health and social services, nonprofit organizations fill the few gaps of the welfare state, following a reverse subsidiarity principle.

Most voluntary organizations are member-serving, as the state fulfils general interest purposes. The field of culture, sports and recreation is the first one, from far, followed by social and professional organizations, consumer defence and child care. Many nonprofits act as lobbies putting pressure upon central and local governments. But it is also in the Nordic countries that the organizations advocating for peace, conflict resolution or Human Rights are many, as well as NGOs channelling a public aid to developing countries higher than 0.7 per cent of GDP, a target that few countries reach.

\footnotetext{
${ }^{6}$ The Charity commission, a public agency inside the Home Office with independent board members, holds the list of charities. To be registered as a charity, a nonprofit organization has to fulfill several cumulative conditions. The charity has to send annual reports and accounts to the Charity Commission
} 
The labor market is characterised by "flexisecurity", a combination of high flexibility and high security of work. Nordic women are working nearly at the same level as men, but they work mainly in the public sphere and often part-time. Despite this fact, volunteering is the highest of all European clusters and the paid/voluntary employment ratio is 0.6 . Therefore the Nordic Third sector is the only one in Europe to rely more on volunteer work than on paid employment. The main religion is Lutheran Protestantism, a quasi-public institution entitled to a church-tax despite the recent separation between church and state. However the influence of religion on the voluntary sector is low and declining.

The resource structure of the sector in the socio-democrat pattern is diversified relying on dues and fees as main resource. Conversely public funding is lower than in the two preceding patterns, one third of total resources, while the level of giving is higher than in the corporatist pattern. Many grant-making foundations afford new resources to nonprofit organizations, the most famous is obviously the Nobel foundation for scientific research.

Some parts of the voluntary sector are in a loose relationship with agricultural, housing and consumer cooperatives and many of them are in a tighter partnership with the mighty laborunions in a crossed relationship. If the membership of the Nordic labor-unions is so high, it is partly due to the advocacy, cultural and social services offered by their voluntary subsidiaries. Conversely labor unions support them.

\subsection{The Mediterranean or emerging cluster}

The Mediterranean countries which illustrate this pattern - Italy, Spain, Portugal, Greece have a recent nonprofit sector because of the restriction or even prohibition of the freedom of association during the authoritarian or dictatorial regimes that these countries went through during the $20^{\text {th }}$ century. Because of its recent origin, the nonprofit sector in this emerging pattern is less developed than the preceding ones, half of the Continental or Anglo-Saxon patterns, and even less than the Nordic one.

Narrower, the nonprofit sector is also in a conflict situation between the state and the main religion, Catholicism (or Orthodoxy in Greece). This conflict calmed down with the secularisation of many previously religious organizations such as schools, hospitals or social services. However a part of the nonprofit sector is linked with left-wing political parties, labor-unions or large cooperative networks while another part is run by catholic congregations. For most countries, the Disestablishment of the Church is still at the agenda; therefore nonprofit organizations are viewed as assets in the competition between the clerical and the secular camps and few of them have a foot in both camps.

The socio-political background is characterized by a weak central government and mighty regional and local governments. Social protection is rising since the entry in European Union, with a mix between Bismarckian (old age and disability) and Beveridgian (health) social security schemes. Southern European countries are yet more rural than the Northern ones and spatial inequalities are deeper. The labor market is characterized by a low flexibility and a low security of work and a mean to high unemployment. Women are working less than in the other clusters. Volunteering is scarce because self-help, mainly by women, still exists inside the extensive family, the parish or the village. But this informal volunteering was recently challenged by the increased participation of women to paid employment, mainly full-time. That is why the paid/volunteer ratio is the same as the Continental cluster's one (1.9). 
As in the Continental pattern, the social service field is the largest part of the nonprofit sector, with the recent dissemination of social cooperatives in Mediterranean countries, after Italy; education comes second, with catholic schools that are less supported by government than in Belgium, France or the Netherlands and more by fees and giving. Then comes local development to reduce spatial inequalities and stress the mighty local power.

The nonprofit sector of Mediterranean countries relies mainly on private commercial resources; public funding have less importance, one third of total resources, as in the Nordic countries. Private individual or corporate contributions are rather high and foundations are scarce but large.

\subsection{The Oriental or post-communist cluster}

This cluster may include all post-communist countries, including those of the former Yugoslavia. However data come from the five countries included in CNP2, Czech Republic, Hungary, Poland, Romania, Slovakia, all new comers in European Union. Of course these countries and their nonprofit organizations are deeply shaped by their recent historical background. Before the fall of the Berlin wall in 1989, there was no freedom of association and the existing ones were mainly in the field of culture, sports and recreation, some of them hiding more political organizations. The most famous of these semi-clandestine organizations is of course Solidarnoc. As these organizations play a major role in the collapse of the communist regimes through the organization of civil society, the term of civil society organizations is the most common in the post-communist countries.

Since 1989, the Third sector grew rapidly in all countries, but as it started nearly from scratch, it is much smaller than in the other European clusters: 1.2 per cent of total employment. It is as professional as in the other clusters (except the Nordic one) with a paid/volunteer ratio of 2.0. During the transition period, the growth of civil society organizations was fuelled by private (Soros Foundation) and public international support. Foreign public assistance was a competition field between US Democracy Network intended to develop civic advocacy, human rights, civic education and environment protection organizations and European Union's more institutional approach promoting the former communist countries to the dominant standards in Europe nearer the Continental pattern (Saulea and Epure, 1998). During the communist regime the State provided all health, education and social services, as well as in The Nordic countries, but not with the same quality standards, therefore the partial privatization of these welfare services is a field of competition among civil society organizations and forprofit businesses. New social cooperatives or mutual societies enter also in competition, despite the bad reputation of cooperatives considered as aftermath of the communist period.

Except Poland, the Oriental countries are small and centralized. Religion has no or little influence on the civil society organizations, with the exception of Poland where the Catholic Church resumed its previous status and retrieved its seized property. Before 1989 indeed, the Polish Catholic parishes and congregations were independent of government resources and became the main distributor of the relief aid from western countries and sheltered civic initiatives, including Solidarnoc (Les, 2000). The labor market of Oriental countries combines high flexibility, low security and high unemployment. The female employment is high and full-time. The social protection is the lowest in Europe; the Social security scheme is a mix of the Beveridgian regime inherited from the communist period and a means tested assistance, near the Anglo-Saxon pattern but lower. 
In this context, associations and foundations mushroom, the later are now more regulated because in some countries they were run by former communist officials who transferred resources from the state by this channel. They are still mainly oriented towards culture and recreation but health and social services are rapidly growing. Their income come first from fees and dues ( 54 per cent) and public funding is lower than elsewhere in Europe, 28 per cent of total resources. Private giving is higher than in the other clusters: this paradoxical fact in low income countries can be explained first by foreign assistance, the bulk of giving in Romania, but also by very favourable tax exemptions and the dissemination to other countries of the one per cent ${ }^{7}$ initiated by Hungary to foster philanthropy.

To conclude this part we have to outline that these clusters are ideal-types, in the sense of Max Weber, more than a description of a moving reality. Many countries do not fit with the ideal-type and could be placed elsewhere. We have chosen to follow approximately in the Table 1 the enlargement of European Union from left to right ${ }^{8}$, but Italy of course is between the Mediterranean and the Continental clusters, Ireland between the Continental and AngloSaxon ones, the Netherlands between the Nordic and the Continental ones and Slovenia between the Oriental and Continental ones. In addition, the clusters we have depicted are changing as the years go by. Are these change exhibiting a converging movement towards a more common European pattern?

\section{Is a converging movement of the five clusters a likely forecast?}

We firstly observe that a converging movement may be observed in the background of the Third sector organizations that is often the necessary condition if not the sufficient one. However the top-down movement coming from European institutions encouraging the nonprofit organizations and disseminating the best practices is ambiguous and a bottom-up convergence towards a European civil society is more likely

\subsection{A convergence is observed in the political social and economic background of the Third sector of the member states}

Most European member-states are facing common trends in their political and socioeconomic backgrounds:

- From the political point of view, the convergence towards a decentralized government and administration in the large member states is the main point. The Decentralization Acts in France $(1983,2003)$ and the 1999 Devolution in UK are examples of this movement to join the mainstream pattern. Conversely the less populated member states keep their centralized government. Another trend towards a bipartite system is less clear. These changes of course have consequences on the partnership with the Third sector

\footnotetext{
${ }^{7}$ According to this Hungarian tax arrangement, the tax-payers are authorised to allocate one per cent of their tax to the nonprofit organization of their choice. Italy has recently adopted the same tax arrangement, at the level of 5 per cent. As a consequence the tax authority was overwhelmed by the demands of nearly all tax-payers...

${ }^{8}$ The dates of the creation and enlargement of European Union are the following : 1957 : Treatise of Rome among the founding member states, Belgium, France, Germany(West), Italy, Netherlands; 1973: Denmark, Ireland, UK; 1981: Greece; 1986: Portugal and Spain; 1995: Austria, Finland, Sweden; 2004: Cyprus, Czech Republic, Estonia, Hungary, Latvia, Lithuania, Malta, Poland, Slovakia, Slovenia; 2007: Bulgaria, Romania.
} 
- The tertiarization of the economy of all member-states, the increased pressure of the global economy on their social security systems and public expenses, the direct comparability of the prices of goods and services inside the Euro-zone, the development of European multinational corporations and intra-Europe migration and tourism are shared economic trends that shape deeply the Third sector

- The European countries share also deep socio demographic trends, such as an ageing society, due to a higher life expectancy and a lower fertility rate, that put pressure on elderly pensions and imply immigration flows from the rest of the world. Another trend is the increasing participation of women to the labor force everywhere, with a difficult conciliation between family and work lives. Religion is growing from scratch in post-communist countries while the other European countries are more and more secular. An educated middle-class exists also everywhere, even in the less developed new member states, giving opportunities for new social entrepreneurs.

- Finally, the cultural backgrounds of the European countries mix as well. Recent Eurobarometers show that the values are more and more similar, especially among the youth. European universities are brought nearer by the Bologna processus ${ }^{9}$ and Erasmus programs make a European course of studies more frequent. Cultural exchanges have often a nonprofit organization as vehicle whether in the linguistic exchanges or the twining of cities.

In this changing background, the convergence of the European countries is consistent with the higher growth rates of GDP in the new than in the ancient member states, in a catch-up movement. It is also consistent with the reconciliation of the ideal-types of social security schemes, Bismarckian, Beverdgian and assistance in new forms of welfare mix where Third sector organizations, including mutual societies, take an increasing and the state a decreasing part (Ascoli and Ranci, 2002). When the level of public social expenditure increases in Mediterranean and in some Oriental countries, it is decreasing in the Nordic countries, including Sweden where social cooperatives or other nonprofit organizations are new actors in the field of new social services in partnership with the government.

What are the consequences of these movements on the five clusters? Of course the first one is that nowadays the Mediterranean cluster, and maybe the Oriental one later, disappears to merge in a mix of the Continental and Anglo-Saxon pattern.

Secondly, the Continental cluster becomes less corporatist, with a decreasing influence of the social partners and consultative bodies and a more neo-liberal spirit in Germany and Austria. In these countries, an opening of the subsidiarity principle to commercial businesses challenges the quasi monopolistic position of the free welfare organizations. A new volunteerism, less official and honorary than the traditional one, took place recently. The Netherlands met a depillarization movement in the late $20^{\text {th }}$ century, when the Catholic and socialist labor-unions unified and the Catholic and Protestant parties merged in a single Christian-democrat Party. In France the decentralization was a great opportunity for the Third sector with a contracting-out of the local powers towards nonprofit organizations, sometimes with bidding quasi-markets and since 2006 the competition increased in the proximity social services.

\footnotetext{
${ }^{9}$ The Bologna processus is a standardization of the courses of study in the European universities, on the American pattern: licence (bachelor's degree), master (graduate), doctor (PHD).
} 
Thirdly, the Anglo-Saxon voluntary organizations became more involved in a partnership with the central government. In UK, the level of social protection rose during the second Blair government up to the mean level of the Continental cluster, reversing the declining trend since the Thatcher government. More, the Third Way (Giddens, 1998) inspiring the labour governments prefers the partnership between the voluntary organizations and the government to the contract and insists on combating social exclusion. Therefore in 1998, Compacts were signed in England, Wales and Scotland that give a larger financial support, acknowledgement and independence to the voluntary sector. Expert groups reinforce the Compacts that are introducing some kind of subsidiarity in the Anglo-Saxon cluster. At the same time new forms of social enterprises appear in UK and Ireland (companies limited by guarantee, industrial and provident societies) beside charities, trusts or friendly societies.

Finally even the very specific Nordic cluster imports some of the features of the other patterns under the pressure a smaller proportion of the GDP going to public social expenditure and a growing part of nonprofit organizationss and cooperatives in the welfare services. Conversely other clusters copy the lobbying methods and the advocacy force of the Nordic one. In this converging movement, the hybrid countries, Italy, Ireland, the Netherlands, Slovenia... play a strategic role of go-between.

\subsection{The ambiguity of the top-down movement coming from European institutions}

Through the ups and downs of his history, the European Union tries to bring together the various clusters and stress that a vibrant nonprofit sector included in a larger Social economy is an important part of its identity. However European institutions have an ambiguous relationship with the Third sector or the Social economy organizations.

On the one hand, the nonprofit and social economy umbrellas have representatives in Brussels, they work more and more together to advocate for their field. The European Commission encourages the creation of platforms of NPOs working on the same field in the various member states. The Commission asks these platforms advice on the policy concerning their fields and facilitates the benchmarking cross-countries to adopt the best practices. This kind of partnership can be interpreted as a corporatist experience due to the identity of the six founding member states and the European Social and Economic Council could be viewed as the crown of this corporatist pattern. The Commission and the European Parliament published as well many reports enhancing the role of the Third sector or Social economy in Europe and launched research tenders on those under-researched topics.

On the other hand, the European treatises consider two categories of economic actors, businesses and public agencies, leaving no place for the specificity of Third sector organizations. The European courts usually condemn the public support to organizations in competition on the same market with standard businesses as unfair competition, with a shift from grants to contracts as a result. This "fair competition" rule may extend soon to the social services of general interest provided by Third sector organizations and transform them in purely commercial businesses. Finally, the Barroso Commission abandoned the Project of a European legal status of association, the first draft of which was written 20 years ago. This draft status of European association was aimed to facilitate cross-border NPOs action.

Of course European institutions have been in stand-by after the crisis provoked by the negative answer of the French and the Dutch to the referendum on Constitutional Treaty in 2005. But the 2007 Lisbon Treatise gave a new start to a more political European Union; this 
treatise maintains the subsidiarity principle and the fair competition on the market as two pillars of the European institutions.

\subsection{A bottom-up European civil society is emerging}

Facing this ambiguous position of European authorities, a bottom-up movement coming from Third sector organizations helps to build the organizational infrastructure of a coming European civil society, next to the existing common market and the future new political institutions that will result of the implementation of the Lisbon Treatise (Anheier, 2002). In fact European authorities pay attention to civil society organizations to fill the gap of democracy, their Achilles' heel, and fight bureaucracy. In this sense the European Third sector could help the Lisbon treatise to be implemented.

Firstly, many ancient or more recent organizations work already cross borders: the Red Cross, Scouts, Caritas, Greenpeace, Medecins sans Frontières, Amnesty International... to quote some of them. Most of them lobby at Brussels, especially on poverty and social exclusion issues and create social ties among the member states. European or International networks are created by the organizations themselves, such as ICFO, created in 1978, to disseminate the best practices in the independent monitoring or self-regulation of fundraising organizations. A more recent example is EUCLID, the European network of Third sector leaders, launched in 2007 in Paris on a British initiative of $\mathrm{ACEVO}^{10}$.

Secondly, membership organizations are by tradition schools of democracy, fostering civic spirit and responsibility. The largest organizations experimented in the last decades a multistakeholder governance, near the future political scheme of the Lisbon Treatise. In a marketoriented economic union, institutional mechanisms to balance self-interest are a necessary but not a sufficient condition and some level of public spirit is needed that the Third sector can afford in addition to the political institutions. At a local level, the organizations created to enhance the friendship between two countries, to foster linguistic, cultural or sports exchanges or to twin European cities are of course building the European civil society. The periodic widening of the European Union opens new fields to this civil society and prevents it to be closed on its privileged position

Thirdly, some associations, and many among the more recent ones, are primarily advocating for another form of economic mainstream arrangement than the shareholder driven form of capitalism. They fight also for a more egalitarian world and more ecological production and consumption. They give a voice to the under-privileged and they try to invent other forms of exchange, money, artistic expression and so on. These anti-establishment NPOs or NGOs could play a major role in the future European policy, as they already did in many World forums or WTO meetings. A role of critical analysis of course, but they could also propose new projects or agenda by using the right of petition included in the Lisbon Treatise as well; the Third sector networks could get hundred of thousands of signatures through the Internet more easily than the political parties or labour unions. This utopian function in building a more vibrant European Union could propose alternative projects, experiment new ways of living together, create new ideologies, new forms of values affirmation. In a sense, the utopian role of civil society organizations is a way to refer to the age of Enlightment, one of the most innovative periods in Europe.

\footnotetext{
${ }^{10}$ Association of Chief Executives in the Voluntary Organizations
} 


\section{Conclusion}

The European Third sector is one and diverse. In every of the five clusters isolated, the actors of the nonprofit and the public sector have understood that cooperation is better than competition: the Third sector can detect new issues, innovate to cope them and experiment alternatives answers to the new questions as well, while the public sector has the right to raise taxes and the duty to secure an equal access of citizens to the public goods. That is why all the clusters and not only the Continental one have built more or less recently a partnership between the Third sector and the government at all levels, local, national or European. Some of the values of the Third sector are nowadays disseminated in the corporate sector as well, under the themes of corporate responsibility and governance. Despite some mismatches and crisis, European Union and the Third sector have to work together to a more civilized globalization. 


\section{References}

Abramovici G.(2005) « La protection sociale dans l'Union Européenne » Statistiques en bref, Population et conditions sociales, Eurostat, 14

Anheier H. (2002) "The Third sector in Europe: Five theses", Civil Society Working Paper 12 Archambault E. (2000) "The third sector as a building block of European citizenship"ISTR $4^{\text {th }}$ Conference, Dublin

Archambault E. (1997) The Nonprofit sector in France, Manchester University Press

Archambault E. (2001) «Y a-t-il un modèle européen de secteur sans but lucratif? », RECMA Revue internationale de l'économie sociale, Paris, 182, novembre 2001, p. 64-83

Archambault E.(2002) « Le travail bénévole en France et en Europe », Revue Française des affaires sociales, Paris, La Documentation Française, 56, p. 13-39

Archambault E. et Kaminski P.(2004) «Vers un compte satellite des institutions sans but lucratif en France », RECMA Revue internationale de l'économie sociale, Paris, 193 et 194

Ascoli U. and Ranci C.,Eds, (2002) Dilemmas of the Welfare Mix; The New Structure of Welfare in an Era of Privatization, New York, Kluwer/Plenum

Burger A. and Dekker P. (2001) The Nonprofit sector in the Netherlands Social and Culture Planbureau, working document 70

Dogan M. and Prewitt K. Eds (2007) the Legitimacy of Philanthropic Foundations: United States and European perspectives, Russell Sage Foundation Press

Donoghue F.(1998) Defining the Nonprofit sector: Ireland The Johns Hopkins Comparative Nonprofit Sector Project, working paper, 28

Esping Andersen G.(1990)The Three worlds of the welfare state, Cambridge, Polity Press

Esping Andersen G.(1999) The social foundations of post-industrial economies, Oxford, Oxford University Press

Esping Andersen G. and associates (2003), Why we need a new welfare state Oxford, Oxford University Press

Flash Eurobarometer (2006) № 202, Youth survey, Gallup Analytical report

Giddens A. (1998) The Third Way: the renewal of social democracy. Cambridge, Polity Press

Kendall J.and Anheier H.(1999). "The Third sector and the European Union Policy Process : an initial evaluation". Journal of European Public Policy, vol. 6, $\mathrm{n}^{\circ} 2$.

Les E. and associates (2000) Defining the Nonprofit sector: Poland The Johns Hopkins Comparative Nonprofit Sector Project, working paper, 36 
Salamon L.M., Anheier H.K.(1997a) « Social origins of Civil society », Voluntas 9, september

Salamon L.M., Anheier H.K.(1997b) and associates, Defining the Nonprofit Sector: A crossnational analysis, Manchester, Manchester University Press. See especially Anheier and Seibel on Germany; Barbetta on Italy; Lundström and Wijkström on Sweden; Kendall and Knapp on UK, Kuti on Hungary

Salamon L.M, Sokolowski, S.W. and associates, (2004) Global Civil Society; Dimensions of the Nonprofit Sector, volume 2, Kumarian Press

Saulean D.and Epure C.(1998) Defining the Nonprofit sector: Romania, The Johns Hopkins Comparative Nonprofit Sector Project, working paper, 32

Schlueter A., Then V. and Walkenhorst P.,Eds,(2002) Foundations in Europe: Society, Management and Law, London, Directory of Social Change

Tocqueville A. de. (1835) De la démocratie en Amérique, Paris, Gallimard, 1951

Traité de Lisbonne (2007) http://www.traite-delisbonne. fr/Traite de_Lisbonne.php?Traite=12 


\begin{tabular}{|c|c|c|c|c|c|}
\hline Clusters & $\begin{array}{c}\text { Continental } \\
\text { (or corporatist) } \\
\text { Austria, Belgium, } \\
\text { France, Germany, Italy, } \\
\text { Netherlands } \\
\end{array}$ & $\begin{array}{c}\text { Anglo-saxon } \\
\text { (or liberal) } \\
\text { United Kingdom, } \\
\text { Ireland }\end{array}$ & $\begin{array}{c}\text { Nordic } \\
\text { (or socio-democrat) } \\
\text { (Denmark), Finland, } \\
\text { [Norway] } \\
\text { Sweden } \\
\end{array}$ & $\begin{array}{l}\text { Mediterranean } \\
\text { (or emerging) } \\
\text { (Greece), Portugal, } \\
\text { Spain }\end{array}$ & $\begin{array}{c}\text { Oriental } \\
\text { (or post-communist) } \\
\text { Czech Republic, Hungar } \\
\text { Poland, } \\
\text { Romania, Slovakia } \\
\end{array}$ \\
\hline $\begin{array}{l}\text { Central government } \\
\text { Local governments } \\
\text { Tax level }\end{array}$ & $\begin{array}{l}\text { Decentralized ; subsidiarity } \\
\text { mighty (fédéralism) } \\
\text { Mean to high }\end{array}$ & $\begin{array}{c}\text { Centralized } \\
\text { Rather mighty } \\
\text { Low }\end{array}$ & $\begin{array}{c}\text { Centralized } \\
\text { Weak } \\
\text { High }\end{array}$ & $\begin{array}{c}\text { Decentralized } \\
\text { Mighty } \\
\text { Low and unclear }\end{array}$ & $\begin{array}{c}\text { Centralized } \\
\text { Weak } \\
\text { Mean to high }\end{array}$ \\
\hline Main religion(s) & $\begin{array}{c}\text { Catholic or } \\
\text { Catholic/Protestant }\end{array}$ & $\begin{array}{c}\text { Protestant UK } \\
\text { Catholic (Ireland) }\end{array}$ & Protestant & $\begin{array}{c}\text { Catholic } \\
\text { Orthodox (Greece) }\end{array}$ & $\begin{array}{l}\text { Catholic or } \\
\text { no religion }\end{array}$ \\
\hline $\begin{array}{l}\text { Labor market: } \\
\text { Flexibility } \\
\text { Sécurity } \\
\text { Unemployment } \\
\text { Women employment }\end{array}$ & $\begin{array}{c}\text { Mean to low } \\
\text { Mean to high } \\
\text { High (except Aus and NL.) } \\
\text { Variable, Part-time }+ \\
\end{array}$ & $\begin{array}{c}\text { High } \\
\text { Low } \\
\text { Low } \\
\text { High, Part-time + }\end{array}$ & $\begin{array}{l}\text { Mean to high } \\
\text { High (flexicurity) } \\
\text { Mean to low } \\
\text { High, Part-time + }\end{array}$ & $\begin{array}{c}\text { Low } \\
\text { Low } \\
\text { Mean to high } \\
\text { Low, Full-time } \\
\end{array}$ & $\begin{array}{l}\text { Mean to high } \\
\text { Low } \\
\text { High } \\
\text { High, Full-time } \\
\end{array}$ \\
\hline $\begin{array}{l}\text { Social Protection } \\
\text { expenses/GDP } \\
\text { Type of social protection } \\
\text { scheme }\end{array}$ & $\begin{array}{l}\text { Mean to high } \\
26 \text { à } 31 \% \\
\text { Bismarckian }\end{array}$ & $\begin{array}{c}\text { UK : mean : } 28 \% \\
\text { Ireland : low } 16 \% \\
\text { Beveridgian /assistantial }\end{array}$ & $\begin{array}{l}\text { Mean to high } \\
26 \text { à } 33 \% \\
\text { Beveridgian }\end{array}$ & $\begin{array}{c}\text { Weak to mean } \\
20 \text { à } 25 \% \\
\text { Bismarckian/Beveridgian }\end{array}$ & $\begin{array}{c}\text { Weak } \\
14 \text { à } 20 \% \\
\text { Beveridgian/assistantia }\end{array}$ \\
\hline $\begin{array}{l}\text { Social Economy } \\
\text { Coopératives } \\
\text { Mutual societies }\end{array}$ & $\begin{array}{c}\text { All kind, large scale coops } \\
\text { Health and insurance, } \\
\text { except Italy }\end{array}$ & $\begin{array}{l}\text { Consumers coops } \\
\text { Housing mutuals, } \\
\text { recent demutualization }\end{array}$ & $\begin{array}{l}\text { Agr. \& consumers coops } \\
\text { Few mutuals }\end{array}$ & $\begin{array}{c}\text { All kind,large scale coops } \\
\text { Few and weak }\end{array}$ & $\begin{array}{l}\text { Ancient, mainly agric. } \\
\text { Very weak or non existe }\end{array}$ \\
\hline Associations & $\begin{array}{l}\text { Many large associations } \\
\text { Growing citizen initiatives }\end{array}$ & $\begin{array}{c}\text { Many, all size voluntary } \\
\text { organizations }\end{array}$ & $\begin{array}{l}\text { Culture and recreation } \\
\text { voluntary org. mainly, }\end{array}$ & $\begin{array}{l}\text { Recent, growing NPOs } \\
\text { Including social coops }\end{array}$ & $\begin{array}{l}\text { Very recent CSOs, cultu } \\
\& \text { recreation mainly }\end{array}$ \\
\hline Fondations & Recent and growing & Many in UK, few in I. & Many, grant-making & Recent and growing & Many, recent ( $1 \%$ of tax \\
\hline
\end{tabular}

${ }^{11}$ Roughly the Enlargement of the European Union goes from left to right. Norway does not belongs to the EU. (Inside brackets) : countries not included in the JH CNP2 


\begin{tabular}{|c|c|c|c|c|c|}
\hline clusters & $\begin{array}{c}\text { Continental } \\
\text { (or corporatist) } \\
\text { Austria, Belgium, } \\
\text { France, Germany, Italy, } \\
\text { Netherlands }\end{array}$ & $\begin{array}{c}\text { Anglo-Saxon } \\
\text { (or liberal) } \\
\text { United Kingdom, } \\
\text { Ireland }\end{array}$ & $\begin{array}{c}\text { Nordic } \\
\text { (or socio-democrat) } \\
\text { (Denmark), Finland, } \\
\text { [Norway], Sweden }\end{array}$ & $\begin{array}{c}\text { Mediterranean } \\
\text { (or emerging) } \\
\text { (Greece), Portugal, } \\
\text { Spain }\end{array}$ & $\begin{array}{c}\text { Oriental } \\
\text { (or post-communist) } \\
\text { Czech Republic, Hungary, } \\
\text { Poland, } \\
\text { Romania, Slovakia, }\end{array}$ \\
\hline $\begin{array}{l}\text { Human resources in the } \\
\text { TS as \% of total employ. }\end{array}$ & $8.0 \%$ & $9.4 \%$ & $6.4 \%$ & $4.3 \%$ & $1.2 \%$ \\
\hline Paid employment (FTE) & $5.2 \%$ & $6.5 \%$ & $2.3 \%$ & $2.8 \%$ & $0.8 \%$ \\
\hline Volunteering (FTE) & $\begin{array}{c}2.7 \% \\
0 \cdot 1\end{array}$ & $2.9 \%$ & $4.1 \%$ & $1.5 \%$ & $0.4 \%$ \\
\hline Paid/voluntary & $1.9:$ professional & $2.2:$ professional & $0.6:$ voluntary & $1.9:$ professional & $2.0:$ professional \\
\hline $\begin{array}{l}\text { Paid employment mainly } \\
\text { directed towards : }\end{array}$ & $\begin{array}{l}\text { Social services }{ }^{+}, \text {Santé, } \\
\text { Education }\end{array}$ & $\begin{array}{l}\text { Education+, culture, } \\
\text { Health(I), social (UK) }\end{array}$ & $\begin{array}{l}\text { Culture \& recreation, } \\
\text { social, professional org. }\end{array}$ & $\begin{array}{l}\text { Social+, education, } \\
\text { Local development }\end{array}$ & $\begin{array}{l}\text { Culture \& recreation }+ \text {, } \\
\text { education, social }\end{array}$ \\
\hline $\begin{array}{l}\text { Volunteering mainly } \\
\text { directed towards : }\end{array}$ & $\begin{array}{c}\text { Culture \& recreation, } \\
\text { social, advocacy }\end{array}$ & $\begin{array}{l}\text { Culture, social, } \\
\text { Local development }\end{array}$ & $\begin{array}{c}\text { Culture \& recreation }+, \\
\text { advocacy }\end{array}$ & $\begin{array}{l}\text { Social, culture \& } \\
\text { recreation }\end{array}$ & $\begin{array}{l}\text { Culture \& recreation, } \\
\text { social }\end{array}$ \\
\hline $\begin{array}{l}\text { Partnership with : } \\
\text { central government : } \\
\text { Social security : } \\
\text { Local governments : }\end{array}$ & $\begin{array}{c}\text { Education } \\
\text { Health, social services } \\
\text { Culture, social, } \\
\text { Local development }\end{array}$ & $\begin{array}{c}\text { Compacts } \\
\text { Partnership with local } \\
\text { municipalities }\end{array}$ & $\begin{array}{l}\text { Beginning in social } \\
\text { services } \\
\text { Partnership with local } \\
\text { municipalities }\end{array}$ & Partnership with regions & $\begin{array}{l}\text { Beginning partnership } \\
\text { in social services }\end{array}$ \\
\hline $\begin{array}{l}\text { Origin of the resources } \\
\text { of the Third sector: } \\
\text { Public sector } \\
\text { Private commercial } \\
\text { Private Giving }\end{array}$ & $\begin{array}{c}58 \% \\
37 \% \\
5 \%\end{array}$ & $\begin{array}{l}47 \%{ }^{12} \\
45 \% \\
9 \%\end{array}$ & $\begin{array}{c}33 \% \\
59 \% \\
7 \%\end{array}$ & $\begin{array}{l}32 \%^{13} \\
49 \% \\
19 \%\end{array}$ & $\begin{array}{l}28 \% \\
54 \% \\
18 \%\end{array}$ \\
\hline
\end{tabular}

Source : Salamon et alii, 2004 and author's calculations

\footnotetext{
${ }^{12}$ We give there the composition of the resources of UK. The resource structure of Ireland is similar to the continental cluster's one (more precisely, exctly the same as Belgium

${ }^{13}$ Data for Spain only
} 